\title{
APLIKASI REGRESI GANDA MODEL COBB-DOUGLAS TERHADAP PRODUKSI TAMBAK BANDENG DI KECAMATAN WONOMULYO
}

\author{
Muhammad Arafat Abdullah *1, St. Haerawati Samil ${ }^{* 2}$ \\ Program Studi Matematika FMIPA Universitas Sulawesi Barat \\ e-mail: arafatmandar@gmail.com; haerawati.samil@gmail.com
}

\begin{abstract}
Abstrak
Secara umum tujuan penelitian ini adalah untuk mengestimasi tingkat produksi tambak bandeng dan menganalisis penggunaan regresi ganda model Cobb-Douglas tentang hubungan antara faktor-faktor produksi dengan tingkat produksi. Faktor-faktor produksi yang diteliti meliputi, jumlah nener $\left(X_{1}\right)$, jumlah pupuk urea $\left(X_{3}\right)$, jumlah pupuk SP36 $\left(X_{2}\right)$, dan pengalaman bertani $\left(X_{4}\right)$. Jumlah responden dalam penelitian ini 120 orang. Dalam penelitian ini, juga digunakan data sekunder yang merupakan data-data penunjang yang diperoleh dari Dinas Kelautan dan Perikanan Kabupaten Polewali Mandar. Regresi ganda model Cobb-Douglas digunakan sebagai alat analisis data dalam penelitian ini. Dengan statistik uji-t, dapat disimpulkan bahwa secara statistik peubah masukan $\left(X_{2}\right)$ dan $\left(X_{3}\right)$ tidak mempunyai pengaruh yang signifikan sedangkan peubah masukan $\left(X_{I}\right)$ dan $\left(X_{4}\right)$ mempunyai pengaruh yang signifikan terhadap produksi tambak bandeng di Kec. Wonomulyo pada alpha 5\%. Dari hasil analisis, jumlah koefesien keelastisan dari keempat peubah masukan yaitu nilai $\eta=1,203$ atau koefisien keelastisan lebih besar dari 1, maka kegiatan produksi sudah berada pada zona I. Oleh karena itu, penambahan faktor produksi secara teknis masih dapat ditingkatkan, sebab penambahan masukan masih memberikan luaran yang besar.
\end{abstract}

Kata kunci: regresi ganda, Cobb-Douglas, Uji-t

\section{PENDAHULUAN}

Matematika sebagai salah satu cabang keilmuan telah banyak mengajarkan manusia mengenal dan menjelaskan fenomena-fenomena yang ada di sekitarnya. Salah satunya adalah statistika yang merupakan cabang matematika yang sangat penting dipelajari untuk menelaah berbagai masalah. Saat ini banyak penerapan penting dari statistika, diantaranya adalah penggunaan model regresi ganda.

Model regresi ganda merupakan sebuah model yang digunakan untuk menganalisis hubungan antar variabel. Hubungan tersebut dapat diekspresikan dalam bentuk persamaan yang menghubungkan variabel terikat $(Y)$ dengan satu atau lebih variabel bebas $\left(X_{1}\right)$, $\left(X_{2}\right), \ldots,\left(X_{k}\right)$. fungsi produksi Cobb-Douglas banyak digunakan dalam menganalisis hubungan masukan (input) dan luaran (output) produksi dibidang ekonomi.

Budidaya tambak di Kecamatan Wonomulyo mempunyai prospek yang cukup baik. Terutama pada tambak ikan bandeng. Petani tambak di Kecamatan Wonomulyo umumnya membudidayakan bandeng secara tradisional dan melakukan pemupukan untuk memacu pertumbuhan ikan bandeng tersebut. Namun seperti yang peneliti amati, banyak petani yang mengeluh pada saat musim panen tiba.

Berikut Tingkat produksi tambak bandeng di Kecamatan Wonomulyo dari tahun 20092013 dapat dilihat pada tabel 1. 
JURNAL SAINTIFIK VOL. 1 NO. 2, JULI 2015

Tabel 1. Produksi Tambak Bandeng Kec. Wonomulyo (Dalam Ton) Tahun 2009-2013

\begin{tabular}{|c|c|}
\hline Tahun & Total Produksi (ton) \\
\hline 2009 & $4.900,52$ \\
\hline 2010 & $3.962,63$ \\
\hline 2011 & $5.143,50$ \\
\hline 2012 & $6.307,10$ \\
\hline 2013 & $5.212,29$ \\
\hline
\end{tabular}

Sumber: Dinas Kelautan dan Perikanan Kab. Pol-Man 2013

Dari tabel diatas dapat dilihat tingkat produksi tambak bandeng di Kecamatan Wonomulyo selama 5 tahun. Dari tahun 2009-2010 terjadi penurunan produksi yang cukup besar yakni menurun sebesar 4.900,52 ton menjadi 3.962,63 ton pertahun pada tahun 2010. Namun pada tahun 2011 sampai tahun 2012 hasil yang dicapai petani terus mengalami peningkatan. Pada tahun 2013 hasil panen yang dicapai petani kembali mengalami penurunan yaitu menjadi 5.212,29 ton pertahun.

Oleh karena itu, diperlukan penaksiran parameter regresi ganda model Cobb-Douglas dengan menggunakan multi variabel yang dapat digunakan untuk menganalisis faktor-faktor yang diduga berpengaruh terhadap produksi tambak bandeng dan menganalisis tingkat Return to scale produksi tambak bandeng di Kec. Wonomulyo.

\section{METODE PENELITIAN}

Jenis penelitian ini adalah kajian pustaka dengan mengumpulkan dan mempelajari pustaka-pustaka yang berkenaan dengan materi penelitian dan survey lapangan. Data yang digunakan adalah data primer yang diperoleh dari petani tambak melalui wawancara langsung dengan menggunakan daftar pertanyaan yang telah disiapkan terlebih dahulu. Sedangkan data sekunder yang berhubungan dengan tambak bandeng diperoleh dari Dinas Kelautan dan Perikanan Kabupaten Polewali Mandar. Populasi dalam penelitian ini meliputi seluruh luas areal tambak bandeng di Kecamatan Wonomulyo sebanyak $2.633 \mathrm{Ha}$, diantaranya luas tambak yang luasnya 1,00 sebanyak $120 \mathrm{Ha}, 2,00 \mathrm{Ha}$ yaitu sebanyak $172 \mathrm{Ha}$ dan tambak yang luasnya 3,00 Ha sebanyak $81 \mathrm{Ha}$. Sampel yang diambil dan dianggap mewakili seluruh populasi yaitu areal tambak yang luasnya $1.00 \mathrm{Ha}$ yaitu sebanyak $120 \mathrm{Ha}$ areal tambak bandeng.

Pada penelitian ini, peneliti menggunakan teknik sampling Simple Random Sampling dan untuk mengetahui faktor-faktor yang mempengaruhi produksi tambak bandeng di Kecamatan Wonomulyo digunakan model fungsi produksi Cobb-Douglas dengan menggunakan metode Ordinary Least Square (OLS). Teknik analisa data yang dipergunakan adalah Fungsi Produksi Cobb-Douglas.

$$
Y=\beta_{0} X_{1}^{\beta_{1}} X_{2}^{\beta_{2}} X_{3}^{\beta_{3}} \cdots X_{k}^{\beta_{k}} \mathcal{E}
$$

Uji Hipotesis :

Untuk menguji pendugaan hipotesis mengenai faktor-faktor yang diduga berpengaruh terhadap produksi tambak bandeng digunakan:

- $R^{2}$ ( koefisien determinasi ) bertujuan untuk mengetahui kekuatan variabel bebas menjelaskan variabel terikat.

- Uji serempak ( $F$-test ), dimaksudkan untuk mengetahui signifikansi statistik koefisien regresi secara serempak. Jika $F$-hit $>F$-tab, maka $\mathrm{H}_{0}$ ditolak dan $\mathrm{H}_{1}$ diterima.

- Uji parsial (t-test), dimakudkan untuk mengetahui signifikansi statistik koefisien regresi secara individu. Jika $t$-hit $>t$-tab, maka $\mathrm{H}_{0}$ ditolak dan $\mathrm{H}_{1}$ diterima.

Untuk memudahkan pemahaman terhadap istilah dan variabel yang digunakan dalam penelitian ini perlu diberikan batasan operasional sebagai berikut: 
1. Produksi atau output $(Y)$ adalah produksi tambak bandeng dalam satuan kilogram $(\mathrm{kg})$ dalam satu kali periode panen.

2. Nener $\left(X_{l}\right)$ adalah jumlah benih ikan bandeng yang ditebarkan per ha dalam satu kali periode panen.

3. Pupuk SP.36 $\left(X_{2}\right)$ adalah pupuk yang digunakan untuk memacu pertumbuhan ikan bandeng, yang diukur dalam satuan kilogram $(\mathrm{kg})$ dalam satu kali periode panen.

4. Pupuk Urea $\left(X_{3}\right)$ adalah pupuk yang juga digunakan untuk memacu perkembangan ikan Bandeng, yang diukur dalam satuan kilogram $(\mathrm{kg})$ dalam satu kali periode panen.

5. Pengalaman Petani Tambak $\left(X_{4}\right)$ yaitu diukur dalam tahun.

\section{Analisis Data}

\section{HASIL DAN PEMBAHASAN}

Berdasarkan nilai-nilai transformasi logaritma, ditentukan persamaan regresi ganda dengan metode kuadrat terkecil $(O L S)$. Dengan hipotesis sebagai berikut:

$\mathrm{H}_{0}$ : tidak ada pengaruh antara faktor-faktor produksi yang ditentukan terhadap tingkat produksi tambak bandeng di Kecamatan Wonomulyo.

$\mathrm{H}_{1}$ : ada pengaruh antara faktor-faktor produksi yang ditentukan terhadap tingkat produksi tambak bandeng di Kecamatan Wonomulyo.

\section{Uji Residual Berdistribusi Normal}

Uji normalitas digunakan untuk mengetahui apakah populasi data berdistribusi normal atau tidak. Cara untuk melihat normalitas residual adalah dengan melihat nilai pada Kolmogorov-Smirnov. Data dinyatakan berdistribusi normal jika signifikansi lebih besar dari 0,05 (Priyatno,2010:71)

Berdasarkan uji Kolmogorov-smirnov pada table 1.4 diperoleh nilai-Sig KolmogorofSmirnov $>\alpha=0,05$. Sehingga asumsi distribusi normal terpenuhi.

\section{Uji Multikolinieritas}

Uji multikolonieritas bertujuan untuk mengetahui apakah antar peubah masukan berkorelasi dengan peubah masukan lainnya. Menurut Santoso (2001) dalam buku Priyatno (2010:81) pada umumnya jika nilai Variance Inflation Factor (VIF) $>5$ maka terdapat persoalan multikolinearitas diantara variabel bebas.

Dari output Coefficients, dapat diketahui bahwa nilai VIF untuk tiap variabel kurang dari 5, maka dapat disimpulkan bahwa pada model regresi tidak ditemukan adanya masalah multikolinearitas.

\section{Uji Autokorelasi}

Uji Autokorelasi bertujuan menguji apakah dalam model regresi linear ada korelasi antara residual pada satu pengamatan dengan pengamatan lain pada model regresi. Metode pengujian menggunakan Uji Durbin-Watson (uji DW) dengan ketentuan sebagai berikut:

1. Jika d lebih kecil dari dl atau lebih besar dari (4-dl), berarti terdapat autokorelasi.

2. Jika d terletak antara du dan (4-du), berarti tidak ada autokorelasi.

3. Jika d terletak antara dl dan du atau diantara (4-du) dan (4-dl), maka tidak menghasilkan kesimpulan yang pasti

Nilai DW yang dihasilkan dari model regresi adalah 2,256. Sedangkan dari tabel DW dengan signifikansi 0,05 dan jumlah data $(n)=120$, seta $k=4$ diperoleh nilai $\mathrm{dL}=1,633, \mathrm{dU}=1,771$ dan 4-dU $=2,229$. Dengan demikian $1,771<2,256>2,229$ atau $\mathrm{dU}<\mathrm{D}>4$-dU dengan kata lain untuk uji autokorelasi tidak ada kesimpulan yang pasti (berada pada daerah keragu-raguan). 
JURNAL SAINTIFIK VOL. 1 NO. 2, JULI 2015

\section{Uji Heteroskedastisitas}

Uji heteroskedastisitas bertujuan untuk mengetahui ada atau tidaknya ketidaksamaan varians dari residual pada model regresi. Jika signifikansi korelasi kurang dari 0,05 maka pada model regresi terjadi masalah heteroskedastisitas (Priyatno,2010:81-87).

Dari hasil output Correlations, dapat diketahui korelasi antara nener dengan Understandardized Residual menghasilkan nilai signifikansi 0.888 , korelasi antara SP36 dengan Understandardized Residual menghasilkan nilai signifikansi 0.813 , korelasi antara Urea dengan Understandardized Residual menghasilkan nilai signifikansi 0.992 dan korelasi antara Pengalaman Bertani dengan Understandardized Residual menghasilkan nilai signifikansi 0.562. Karena nilai signifikansi korelasi lebih dari 0.05 , maka dapat disimpulkan bahwa pada model regresi tidak ditemukan adanya masalah heteroskedastisitas.

Untuk menganalisis faktor-faktor produksi yang mempengaruhi tingkat produksi tambak bandeng digunakan model Cobb-Douglas sebagai berikut:

$$
Y^{*}=\beta_{0}{ }^{*}+\beta_{1} X_{1 i}{ }^{*}+\beta_{2} X_{2 i}{ }^{*}+\beta_{3} X_{3 i}{ }^{*}+\beta_{4} X_{4 i}{ }^{*}+\varepsilon_{i}{ }^{*}
$$

Dari hasil analisis diperoleh:

$R=0,913$

$R^{2}=0,833$

$R^{2}$ adj $=0,827$

Std error $=0,37004$

Angka $R^{2}$ ini dapat digunakan untuk melihat besarnya pengaruh peubah $X_{1}, X_{2}, X_{3}$, dan $X_{4}$ secara bersama-sama terhadap $Y$ dengan cara menghitung Koefisien Determinasi (KD) (Kurniawan,2008). Adapun rumus yang digunakan sebagai berikut:

$$
\begin{aligned}
K D & =R^{2} \times 100 \% \\
& =0,833 \times 100 \% \\
& =83,3 \%
\end{aligned}
$$

Sehingga dapat diartikan bahwa pengaruh peubah masukan $X_{1}, X_{2}, X_{3}$, dan $X_{4}$ secara bersama-sama terhadap $Y$ adalah sebesar $83,3 \%$, dan sisanya sebesar $16,7 \%$ karena pengaruh faktor lain yang tidak terlibat dalam penelitian ini.

Selanjutnya diperoleh nilai-nilai:

$$
\hat{\beta}_{0}^{*}=-1,174 \quad \hat{\beta}_{1}=0,835 \quad \hat{\beta}_{2}=0,172 \quad \hat{\beta}_{3}=-0,147 \quad \hat{\beta}_{4}=0,343
$$

Nilai $\hat{\beta}_{0}{ }^{*}$ yang dihasilkan pada analisis data transformasi adalah $\ln \beta_{0}$. Nilai tersebut harus ditransformasikan dulu kedalam $\beta_{0}$ dengan menghitung nilai eksponen dari $\ln \beta_{0}$ jadi,

$$
\begin{aligned}
& \hat{\beta}_{0}{ }^{*}=\ln \hat{\beta}_{0}=-1,174 \\
& \hat{\beta}_{0}=\operatorname{anti} \ln (-1,174)=0,309
\end{aligned}
$$

Berdasarkan nilai-nilai $\hat{\beta}_{0}, \hat{\beta}_{1}, \hat{\beta}_{2}, \hat{\beta}_{3}, \hat{\beta}_{4}$ yang diperoleh, maka persamaan fungsi produksi Cobb-Douglas tersebut dapat ditulis sebagai berikut:

$$
\hat{Y}=0,309 X_{1}^{0,835} X_{2}^{0,172} X_{3}^{-0,147} X_{4}^{0,343}
$$

Hasil analisis regresi fungsi Cobb-Douglas yang telah diperoleh menunjukkan bahwa:

a) Nilai $\hat{\beta}_{0}=0,309$. Hal ini berarti bahwa konstanta sebesar 0,309. menunjukkan jika peubah masukan dianggap konstan, maka tingkat produksi bandeng sebesar $0,309 \%$.

b) Nilai $\hat{\beta}_{1}=0,835$. Hal ini berarti bahwa untuk masukan $X_{l}$, produksi telah berada pada tahap menurun (decreacing) karena koefesien keelastisan produksi kurang dari satu. Jadi, penambahan masukan $X_{1}$ sebesar $1 \%$ hanya akan meningkatkan luaran sebesar $0,835 \%$. 
c) Nilai $\hat{\beta}_{2}=0,172$. Hal ini berarti bahwa untuk masukan $X_{2}$, produksi telah berada pada tahap menurun (decreacing) karena koefesien keelastisan produksi kurang dari satu. Jadi, penambahan masukan $X_{2}$ sebesar $1 \%$ hanya akan meningkatkan luaran sebesar $0,172 \%$.

d) Nilai $\hat{\beta}_{3}=-0,147$. Hal ini berarti bahwa terjadi penurunan luaran sebesar $0,147 \%$ untuk setiap penambahan masukan $X_{3}$ sebesar $1 \%$.

e) Nilai $\hat{\beta}_{4}=0,343$. Hal ini berarti bahwa untuk masukan $X_{4}$ produksi telah berada pada tahap menurun (decreacing) karena koefesien keelastisan produksi kurang dari satu. Jadi, penambahan masukan $X_{4}$ sebesar $1 \%$ hanya akan meningkatkan luaran sebesar $0,343 \%$.

Ditinjau dari angka-angka statistik, nampak bahwa $\left(X_{3}\right)$ mempunyai pengaruh yang negatif terhadap tingkat produksi tambak bandeng. Hal ini menyatakan bahwa bila jumlah input pupuk Urea ditambah penggunaannya sedangkan input lain tetap, maka tambahan output yang dihasilkan mula-mula naik, kemudian seterusnya menurun bila input tersebut terus ditambahkan.

Kemudian tahap selanjutnya yaitu pengujian untuk menentukan kebermaknaan regresi dan kebermaknaan masing-masing peubah masukan. Pengujian dilakukan dengan Uji- $f$ pada tabel ANAVAR untuk mengetahui bagaimana pengaruh peubah masukan terhadap hasil produksi tambak bandeng per Ha.

Diketahui:

JKR $=78,419 \quad$ RKR $=19,605 \quad$ JKK $=15,747 \quad$ RKK $=0,137 \quad$ JKT $=94,166$

$f_{\text {hitung }}=\frac{R K R}{R K K}=143,10 \quad \mathrm{P}($ sign $)=0,000$

dk pembilang $=\mathrm{m}=4$

dk penyebut $=\mathrm{n}-\mathrm{m}-1=120-4-1=115$

$f_{\text {tabel }}=f_{0,05}=2,44$

1. Pengujian Serentak

Hasil pengujian model regresi secara serentak dengan hipotesis:

$\mathrm{H}_{0}: \beta_{1}=\beta_{2}=\beta_{3}=\beta_{4}=0$; melawan

$\mathrm{H}_{1}$ : minimal satu nilai $\beta_{i} \neq 0$, dimana $i=1,2,3$, dan 4

Dengan kriteria pengujian:

a. Jika $\left(f_{\text {hitung }}>f_{\text {tabel }}\right)$ maka $\mathrm{H}_{0}$ ditolak dan $\mathrm{H}_{1}$ diterima.

b. Jika $\left(f_{\text {hitung }}<f_{\text {tabel }}\right)$ maka $\mathrm{H}_{0}$ diterima dan $\mathrm{H}_{1}$ ditolak.

Berdasarkan tabel ANOVA diperoleh bahwa nilai $f_{\text {hitung }}>f_{\text {tabel }}$ yaitu 143,10 $>2,44$. sehingga dapat disimpulkan bahwa $\mathrm{H}_{0}$ ditolak dan $\mathrm{H}_{1}$ diterima.

2. Pengujian Individu

Untuk mengetahui peubah masukan mana yang menunjukkan pengaruh yang signifikan maka dilakukan pengujian individu atau Uji- $t$ dengan $\alpha=0,05$, melalui hipotesis:

$$
\begin{aligned}
& \mathrm{H}_{0}: \beta_{i}=0 \\
& \mathrm{H}_{1}: \beta_{\mathrm{i}} \neq 0
\end{aligned}
$$

dimana, $i=1,2,3,4 \quad$ dan $t_{\text {tabel }}=t_{(\{1-\alpha\}\{n-k-1\})}=1,658$

diperoleh: 
JURNAL SAINTIFIK VOL. 1 NO. 2, JULI 2015

a. Nilai $t$ hitung dari koefisien regresi $\beta_{1}$ adalah $11,968,\left(t_{\text {hitung }}>t_{\text {tabel }}\right)$, dengan nilai $p($ sign $)=$ 0,000 , yang artinya $(0,000<0,05)$. Disimpulkan bahwa peubah $\left(X_{l}\right)$ mempunyai pengaruh yang signifikan terhadap tingkat produksi tambak bandeng.

b. Nilai $t$ dari koefisien regresi $\beta_{2}$ adalah $1,051\left(t_{\text {hitung }}<t_{\text {tabel }}\right)$, dengan nilai $p(\operatorname{sign})=0,295$, yang artinya $(0,295>0,05)$. Dengan demikian disimpulkan bahwa peubah $\left(X_{2}\right)$ tidak mempunyai pengaruh yang signifikan terhadap tingkat produksi tambak bandeng.

c. Nilai $t$ dari koefisien regresi $\beta_{3}$ adalah $-0,813\left(t_{\text {hitung }}<t_{\text {tabel }}\right)$, dengan nilai $p($ sign $)=0,418$, yang artinya $(0,418>0,05)$. Dengan demikian disimpulkan bahwa peubah $\left(X_{3}\right)$ juga tidak mempunyai pengaruh yang signifikan terhadap tingkat produksi tambak bandeng.

d. Nilai $t$ dari koefisien regresi $\beta_{4}$ adalah $6,725\left(t_{\text {hitung }}>t_{\text {tabel }}\right)$, dengan nilai $p($ sign $)=0,000$, yang artinya $(0,000<0,05)$. Dengan demikian disimpulkan bahwa peubah $\left(X_{4}\right)$ mempunyai pengaruh yang signifikan terhadap tingkat produksi tambak bandeng.

Jika hanya berpatokan pada analisis di atas, maka disimpulkan bahwa kedua pupuk yang digunakan tidak mempunyai pengaruh yang signifikan terhadap tingkat produksi tambak bandeng per ha di Kecamatan Wonomulyo. Kemudian selanjutnya ingin diketahui Apakah petani tambak bandeng di Kecamatan Wonomulyo sudah beroperasi pada daerah Rasional atau belum? Untuk menentukan pada tahap apa kegiatan produksi tercapai jika kita menggunakan peubah masukan, besarnya koefisien keelastisan dari berbagai masukan tersebut digunakan sebagai kriteria.

Dari hasil olahan data dengan menggunakan SPSS 16.0 di peroleh nilai koefesien keelastisan masing-masing peubah masukan yaitu:

$$
\beta_{1}=0,835 \quad \beta_{2}=0,172 \quad \beta_{3}=-0,147 \quad \beta_{4}=0,343
$$

Untuk menentukan pada tahap apa kegiatan produksi tercapai, jika digunakan peubah masukan, maka nilai dari koefesien keelastisan dari keempat peubah masukan tersebut dijumlahkan atau $\eta=\beta_{1}+\beta_{2}+\beta_{3}+\beta_{4}$. Dengan ketentuan sebagai berikut:

a. Jika besarnya koefisien keelastisan lebih besar dari satu, dapat disimpulkan bahwa kegiatan produksi masih berada pada tahap naik (increasing) atau zona I. Produksi masih dapat ditingkatkan sebab penambahan masukan masih memberikan luaran yang lebih besar.

b. Jika koefisien keelastisan berada pada rentang nilai antara 0 dan $1(0<\eta<1)$, kegiatan produksi sudah berada pada tahap rasional atau zona II. Penambahan faktor produksi secara teknis tidak diperlukan lagi, sebab sudah mencapai daerah optimal.

c. Jika salah satu koefisien keelastisan sudah negatif, atau jumlah koefisien tersebut menjadi negatif maka hal itu berarti penggunaan salah satu faktor produksi sudah melampaui batas, sehingga diperlukan pengurangan atau realokasi dari faktor-faktor produksi yang digunakan (Tiro,2007:367-370).

Sehingga:

$$
\begin{aligned}
\eta & =\beta_{1}+\beta_{2}+\beta_{3}+\beta_{4} \\
& =0,835+0,172-0,147+0,343 \\
& =1,203
\end{aligned}
$$

Karena nilai $\eta=1,203$ atau koefisien keelastisan lebih besar dari 1, maka kegiatan produksi sudah berada pada tahap naik atau zona I. Oleh karena itu, penambahan faktor produksi secara teknis masih dapat ditingkatkan, sebab penambahan masukan masih memberikan luaran yang besar. 


\section{KESIMPULAN}

- Persamaan normal untuk regresi ganda model Cobb-Douglas yang terdiri dari multi variabel adalah sebagai berikut:

$$
\begin{aligned}
& \sum_{i=1}^{n} Y_{i}^{*}=\hat{\beta}_{0}^{*} \sum_{i=1}^{n} 1+\hat{\beta}_{1} \sum_{i=1}^{n} X_{1 i}{ }^{*}+\hat{\beta}_{2} \sum_{i=1}^{n} X_{2 i}{ }^{*}+\hat{\beta}_{3} \sum_{i=1}^{n} X_{3 i}{ }^{*}+\hat{\beta}_{4} \sum_{i=1}^{n} X_{4 i}{ }^{*} \\
& \sum_{i=1}^{n} X_{1 i}{ }^{*} Y_{i}^{*}=\hat{\beta}_{0}{ }^{*} \sum_{i=1}^{n} X_{1 i}{ }^{*}+\hat{\beta}_{1} \sum_{i=1}^{n} X_{1 i}{ }^{* 2}+\hat{\beta}_{2} \sum_{i=1}^{n} X_{2 i}{ }^{*} X_{1 i}{ }^{*}+\hat{\beta} \sum_{i=1}^{n} X_{3 i}{ }^{*} X_{1 i}{ }^{*}+\hat{\beta}_{4} \sum_{i=1}^{n} X_{4 i}{ }^{*} X_{1 i}{ }^{*} \\
& \sum_{i=1}^{n} X_{2 i}{ }^{*} Y_{i}^{*}=\hat{\beta}_{0}{ }^{*} \sum_{i=1}^{n} X_{2 i}{ }^{*}+\hat{\beta} \sum_{i=1}^{n} X_{1 i}{ }^{*} X_{2 i}{ }^{*}+\hat{\beta} 2 \sum_{i=1}^{n} X_{2 i}{ }^{* 2}+\hat{\beta} 3 \sum_{i=1}^{n} X_{3 i}{ }^{*} X_{2 i}{ }^{*}+\hat{\beta} \sum_{i=1}^{n} X_{4 i}{ }^{*} X_{2 i}{ }^{*} \\
& \sum_{i=1}^{n} X_{3 i}{ }^{*} Y_{i}^{*}=\hat{\beta}_{0}{ }^{*} \sum_{i=1}^{n} X_{3 i}{ }^{*}+\hat{\beta}_{1} \sum_{i=1}^{n} X_{1 i}{ }^{*} X_{3 i}{ }^{*}+\hat{\beta}_{2} \sum_{i=1}^{n} X_{2 i}{ }^{*} X_{3 i}{ }^{*}+\hat{\beta} 3 \sum_{i=1}^{n} X_{3 i}{ }^{* 2}+\hat{\beta}_{4} \sum_{i=1}^{n} X_{4 i}{ }^{*} X_{3 i}{ }^{*} \\
& \sum_{i=1}^{n} X_{4 i}{ }^{*} Y_{i}^{*}=\hat{\beta}_{0}{ }^{*} \sum_{i=1}^{n} X_{4 i}{ }^{*}+\hat{\beta}_{1} \sum_{i=1}^{n} X_{1 i}{ }^{*} X_{4 i}{ }^{*}+\hat{\beta}_{2} \sum_{i=1}^{n} X_{2 i}{ }^{*} X_{4 i}{ }^{*}+\hat{\beta} 3 \sum_{i=1}^{n} X_{3 i}{ }^{*} X_{4 i}{ }^{*}+\hat{\beta}_{4} \sum_{i=1}^{n} X_{4 i}{ }^{* 2}
\end{aligned}
$$

- Pengaruh peubah masukan (input) terhadap hasil produksi (output) tambak bandeng per Ha di Kecamatan Wonomulyo adalah :

a. Nilai $\hat{\beta}_{0}=0,309$. Hal ini berarti bahwa konstanta sebesar 0,309. menunjukkan jika peubah masukan dianggap konstan, maka tingkat produksi bandeng sebesar 0,309\%.

b. Nilai $\hat{\beta}_{1}=0,835$. Hal ini berarti bahwa untuk masukan $X_{1}$, produksi telah berada pada tahap menurun (decreacing) karena koefesien keelastisan produksi kurang dari satu. Jadi, penambahan masukan $X_{1}$ sebesar 1\% hanya akan meningkatkan luaran sebesar $0,835 \%$.

c. Nilai $\hat{\beta}_{2}=0,172$. Hal ini berarti bahwa untuk masukan $X_{2}$, produksi telah berada pada tahap menurun (decreacing) karena koefesien keelastisan produksi kurang dari satu. Jadi, penambahan masukan $X_{2}$ sebesar 1\% hanya akan meningkatkan luaran sebesar $0,172 \%$.

d. Nilai $\hat{\beta}_{3}=-0,147$. Hal ini berarti bahwa terjadi penurunan luaran sebesar $0,147 \%$ untuk setiap penambahan masukan $X_{3}$ sebesar $1 \%$.

e. Nilai $\hat{\beta}_{4}=0,343$. Hal ini berarti bahwa untuk masukan $X_{4}$ produksi telah berada pada tahap menurun (decreacing) karena koefesien keelastisan produksi kurang dari satu. Jadi, penambahan masukan $X_{4}$ sebesar 1\% hanya akan meningkatkan luaran sebesar $0,343 \%$.

- Dari hasil analisis, jumlah koefesien keelastisan dari keempat peubah masukan yaitu jumlah nener, jumlah pupuk SP36, jumlah pupuk Urea dan pengalaman bertani adalah $\eta=$ 1,203 atau koefisien keelastisan lebih besar dari 1, maka kegiatan produksi sudah berada pada tahap naik atau zona I. Oleh karena itu, penambahan faktor produksi secara teknis masih dapat ditingkatkan, sebab penambahan masukan masih memberikan luaran yang besar.

\section{Saran}

- Hasil analisis data pada penelitian ini menggunakan software SPSS 16.0. untuk itu, diharapakan pada peneliti-peneliti berikutnya untuk membandingkan hasil analisisnya dengan menggunakan Software SAS atau Software Minitab. 


\section{JURNAL SAINTIFIK VOL. 1 NO. 2, JULI 2015}

- Data yang digunakan pada penelitian ini adalah data penelitian sesaat, sehingga analisis regresi ini hanya dilakukan pada satu periode produksi saja. Dengan demikian hasil analisisnya belum dapat menggambarkan usaha tani secara menyeluruh. Khususnya perkembangan usaha tani budidaya tambak bandeng dalam jangka panjang.

\section{DAFTAR PUSTAKA}

Bank Indonesia. Pola Pembiayaan Usaha Kecil (PPUK) Budidaya Bandeng. tbtlkm@bi.go.id. Diakses: 02/07/2013.

Djauhari, A. 1999. Pendekatan Fungsi Cobb-Douglas Dengan Elastisitas Variabel Dalam Study Ekonomi Produksi, Suatu Contoh: Aplikasi Pada Padi Sawah. Jurnal Informatika Pertanian, Vol. 8. Diakses : 11/03/2013.

Herawati, E. 2008. Analisis Pengaruh Faktor Produksi Modal, Bahan Baku, Tenaga kerja dan Mesin Terhadap Produksi Glyserine Pada PT. Flora Sawita Chamindo Medan. Tesis. Semarang: Univeritas Diponegoro.

Indriana, A. 2011. Analisis Produksi Uaha Tani Jambu Air di Kabupaten Demak. Skripsi. Semarang: Universitas Diponegoro.

Kurniawan, D. 2008. Regresi Linear (Linear Regression). http://ineddeni.wordpress.com. Diakses: 15/04/2013.

Priyatno, D. 2010. Paham Analisa Statistik Data dengan SPSS. Yogyakarta : MediaKom.

Putong, I. 2003. Pengantar Ekonomi Mikro \& Makro.

Putranto, D.A. 2007. Analisis Efesiensi Produksi Kasus pada Budidaya Penggemukan Kepiting Bakau di Kabupaten Pemalang. Tesis. Semarang: Universitas Diponegoro. http://www.google.com/aplikasi/Cobb-Douglas. Diakses: 11/03/2013.

Ramadhani, Y. 2011. Analisis Efisiensi, Skala dan Elastisitas Produksi Dengan Pendekatan Cobb-Douglas dan Regresi Berganda. Jurnal Teknologi, Vol. 4, No. 1, 61-53. Yuliastuti@akprind.ac.id. Diakses 07/06/2013.

Seber, G. \& Lee, A. Linear Regression Analysis. Second Edition. New Zealand : Departement Of Statistics. University Of Anckland

Spyros, dkk. Metode dan Aplikasi Peramalan. Edisi Kedua. Jilid 1. Jakarta: Erlangga

Tajerin. 2007. Efisiensi Teknis Usaha Budidaya Pembesaran Lele di Kolam (Study Kasus di Kabupaten Tulung Agung, Jawa Timur). Jurnal Ekonomi Pembangunan, Vol.12 No. 1, Hal 37-48. Jerin_Jmhr@yahoo.com. Diakses 07/06/2013.

Tiro, M.A. 2007. Statistika Terapan Untuk Ilmu Ekonom dan Ilmu social. Edisi kedua. Makassar : Andira Publisher.

Tumanggor, D.S. 2009. Analisis Faktor-faktor Yang Mempengaruhi Produksi Coklat di Kabupaten Dairi. Tesis. Medan: Universitas Sumatra Utara.

Wahab, A. 2011. Statistik Terapan. Majene: FMIPA Universitas Sulawesi Barat.

Wahab, A. 2012. Pengantar Statistik Untuk Pendidikan dan Sains. Majene : Kutub Wacana

Wiwit. 2006. Analisis Pengaruh Faktor Produksi terhadap Produksi Industri Pengasapan Ikan di Kota Semarang. Skripsi. Semarang: Universitas Diponegoro. www.scribd.com/doc/.../Regresi-Ganda. Diakses: 01/08/2012 